\title{
A magyar katonai rádiófelderítés története
}

A hírszerzés egyidős az emberiséggel. Az emberi kíváncsiság, amivel törekszik adatok-információk gyűjtésére saját céljai elérése érdekében a kezdetektől való, létezik és létezni fog mindörökké. Egy gyakran idézett klasszikus, SZUN CE szerint is fontos a hírek, információk gyüjtése.

„Ha (az ellenség) hadseregére csapást akarunk mérni, ha (az ellenség) városát meg akarjuk ostromolni, ha (az ellenség) vezérét meg akarjuk ölni, akkor előre meg kell ismernünk a hadvezér örségének, környezetének, látogatóinak, ajtónállóinak és személyes öreinek családi és személynevét, meg kell parancsolnunk a kémeknek, hogy mindezt fürkésszék ki."

A történelem során az információhordozó közeg változott. Hírvivők, futárok, állati erővel célba juttatott nyílt, titkosított üzenetek és végül a technika vívmányait kihasználó módszerek terjedtek el, elsősorban a katonai, később a civil alkalmazásokban. Így történt ez a XIX. század végén is, amikor felfedezték a rádiózás elvét, forradalmasítva az információtovábbítás módszereit. Kezdetben azonban - 1896. III. 24-én Sztefanovics POPOV orosz fizikus sikeres kísérletet hajtott végre, mely során rádiójeleket küldött a szentpétervári egyetem egyik épületéből a másikba—, még kevesen sejtették milyen hatással lesz ez a jövőre nézve.

Ahogy azonban várható volt, a fegyveres erők hamarosan felismerték a rádióhíradás jelentőségét a hadviselésben. Sztefanovics POPOV is azzal töltötte későbbi kutatóéveit, hogy a rádióhullámok átvitelét minél nagyobb távolságra terjessze ki. A kronstadti tengerészeti akadémián a Finn-öbölben állomásozó orosz flotta minél sikeresebb kommunikációja érdekében dolgozott, egészen 1905 végén bekövetkezett haláláig.

Ahogy a kor modern hadseregeiben a kommunikációra eszközöket tömegesen rendszeresítették, úgy nőtt az igény a hírváltások forgalmának lehallgatására, az adatok-információk továbbítására. Így jött létre a rádiófelderítés, új felderítési ágként, a modern kor gyermekeként.

$\mathrm{Az}$ Osztrák Magyar Monarchiában is megjelentek a morzetávírók, majd a távbeszélö összeköttetésre is alkalmas rádió-berendezések. A híradócsapatok föleg az „1877” és „1892” mintájú rádióeszközöket használták a föparancsnokság intézkedéseinek eljuttatására a végrehajtó alakulatokhoz.

Az Osztrák Magyar Monarchia haderejében korán, 1896-tól alkalmaztak rádiólehallgató távírászokat, akiket az ausztriai Tullnban képeztek ki feladataikra, egészen az I. világháború végéig.

Az Osztrák Magyar Monarchia véderejében 18 féle hírszerző szolgálati ág müködött, amelyek közül a távbeszélő-lehallgatók és a rádiólehallgatók képezték a későbbi rádiófelderítés elődjét. ${ }^{2}$

Érdekes adalék a történelmi visszaemlékezésekhez, hogy a rádiófelderítésben résztvevők ekkoriban nem önálló szakcsapatként, hanem a híradó szolgálat részeként hajtották végre feladataikat. Ez így is maradt egészen 1942. X. 1-ig, amikor a 101. híradó ezredből kiváló erőkből felállították a 101. rádiófelderítő zászlóaljat. Így jött létre egy új, önálló szolgálat, a magyar katonai rádiófelderítés.

Hamarosan nyilvánvalóvá vált az a tény, hogy a rádiófelderítés megjelenésével óhatatlanul is illetéktelen kezekbe kerülhettek a nyílt forgalmazásban továbbított közlemények. Így hamarosan megjelentek a kódkönyvek, kódtáblázatok, hogy a minősített adatok védettsége fokozható legyen. Természetesen erre a lépésre is hamarosan megérkezett a válasz, létrejöttek a kód- és rejtjelfejtő szervezetek.

Az ismert kriptográfus, David KAHN szerint az első világháború előtt két ország hadereje készült fel a kriptográfiai kihívásokra: Franciaország és az Osztrák-Magyar Monarchia védereje. Ez utóbbi állományába tartozó Andreas FIGL százados lett az első ilyen szervezet vezetője 1911-ben. Ekkor Anglia, Németország és Oroszország sem ismerte még fel a rádiólehallgatás, rejtjelfejtés jelentőségét, elhanyagolta e terület fejlesztését. Oroszország azonban hamarosan nagy árat fizetett ezért a rövidlátásáért.

\section{Az Osztrák-Magyar Monarchia rádiófelderítése az I. világháborúban}

A XX. század első magyar rejtjel- és kódfejtőjének a morva születésü POKORNY Hermann vezérezredest (ekkor még vk. szds.) tekinthetjük, aki az I. világháborúban, mindenféle elöképzettség nélkül kezdett foglalkozni, a keleti frontra vezényelten, az orosz katonai táviratokkal. Nem értette, hogy a német és az osztrák hadvezetés miért nem tulajdonít jelentőséget a rejtjelezett orosz közleményeknek. Úgy gondolta, hogy a nyílt táviratoknál érdekesebb, értékesebb információkhoz juthat megfejtésükkel. Felettesei gyanakodva, nem túl nagy meggyőződéssel hagyták, hogy a fiatal tiszt megszervezze a lehallgató és a rejtjelfejtő szolgálatot. Hamarosan megszolgálta az elöljárói 
bizalmat, és az I. világháború alatt három kiemelkedő eseményben bizonyultak nélkülözhetetlennek az általa megszerzett adatok, döntően befolyásolva a hadmüveletek sikerét. 1914. IX. 6. és 1916. III. 1. között mintegy 10000 lehallgatott táviratot fejtettek meg beosztottjaival közösen.

POKORNY Hermann és beosztottai rádiófelderítő tevékenységének haszna első ízben 1914-ben jelentkezett. Ez év decemberében az 1. osztrák-magyar és a 9. német hadsereg megállította a négy(!) hadseregből álló orosz „gőzhengert” a mai lengyelországi San Visztula mentén. A POKORNYék által lehallgatott és megfejtett 240 távirat segítségével megállapítható volt az orosz támadási szándék, a súlypontképzés módja, helye és állománybeli összetétele, mely segítségével végrehajthatóak voltak a szükséges csapatmozgások. ${ }^{3}$ (I.sz. melléklet)

Másodjára 1915 márciusában, a gorlicei áttörésnél játszott kulcsfontosságú szerepet a rejtjelfejtés. A megfejtett 205 távirati információ segítette hozzá a hadvezetést számos hadászati cél eléréséhez és 1915. VI. 2-ára Przemysl visszafoglalásához. ${ }^{4}$ (II.sz. melléklet)

POKORNY Hermann I. világháborús karrierjének csúcsát jelentette, amikor az általa vezetett részleg 53 távirat megfejtésének segítségével az osztrák-magyar és a német csapatok 1915. VIII. 25-én elfoglalják Breszt-Litovszk városát. ${ }^{5}$ (III.sz. melléklet)

A rádiófelderítés történetének taglalásakor mindenképpen szükséges bővebben foglalkozni POKORNY Hermann vezérezredes személyével. E páratlan karriert befutó, ${ }^{6}$ tehetséges és később méltatlanul feledésbe merült emlékü katonatiszt 1882. IV. 7-én született a morvaországi Kremsierben (Kromerizben). A katonai iskolák elvégzése után tiszti pályafutását hadnagyként, Bécsben kezdte meg 1901. XI. 1-én. Német anyanyelve mellett csehül valószínüleg még a szülőföldjén megtanult, később pedig a bolgár, lengyel nyelvet is elsajátította, majd 1911-ben — mindössze három hónap alatt — az orosz nyelvet is megtanulta. A II. világháború után franciául is tanult, a magyart csak 1918-ban sajátította el. Az I. világháború időszakában az Evidenzbüro ${ }^{7}$ kötelékében is teljesített szolgálatot. 1917-ben diplomáciai rátermettségének következtében részt vett az I. világháborút lezáró BresztLitovszk-i béketárgyalásokon. Bár az anyanyelve német volt, az Osztrák-Magyar Monarchia összeomlása után, STROMFELD Aurél hívására, csatlakozott a magyar haderőhöz. Úgy érezte, hogy morva születésüként Ausztriában, mint „Zugraster” (Zugereist, bécsi dialektusban - befurakodott) lehetne csak, ezért választotta Magyarországot új hazájának. A Tanácsköztársaság bukása és a trianoni békediktátum után megszervezte és 1920-1925 között vezette a rejtett vezérkar ${ }^{8}$ „X” osztályát. 1921. október második felében az általuk megfejtett rejtjelanyagok segítségével látták el hiteles információval a Magyar Királyi Külügyminisztériumot és Magyar Királyi Honvédelmi Minisztériumot IV. Károly puccskísérletéröl. ${ }^{9}$

Az ezt követő években különböző gyalogostiszti és vámőrségi beosztásokban szolgált. ${ }^{10}$

1935-ben véglegesen nyugdíjazták. Nyugállományba helyezése után magánvállalatoknál és a Hadtörténeti Levéltárban dolgozott.

1945-ben Rogyin Jakovlevics MALINOVSZKIJ Hevesben lévő föhadiszállásán dolgozott és a marsall kérésére átadta a I. világháborúban megfejtett orosz rejtjelanyagok dokumentációját. Rövid külügyminisztériumi szolgálatot követően, mint horthysta tisztet eltávolították és később a nyugdiját is megvonták.

1960-ban Budapesten halt meg és Gödöllőn temették el. ${ }^{11}$

Páratlanul kalandos életet élt. Sokoldalú katonatiszt pályafutásának főbb állomásai egyben korszakunk fordulópontjai is voltak. (IV.sz. melléklet)

\section{Magyar rádiófelderítés 1920-1947}

Trianon után a békeszerződésben foglaltak betartását az ANTANT Magyarországra delegált Szövetségközi Katonai Ellenőrző Bizottsága ellenőrizte. A szigorú felügyelet csak 1927 után enyhült. ${ }^{12}$ A haderőszervezés azonban1920-1927 között titokban is folytatódott.

A honvédelmi tárca „X” osztály (sifre) nyersanyagait elsősorban a Magyar Királyi Posta által beszolgáltatott diplomáciai küldemények képezték és kevés írásos információ maradt fenn arról, vajon a Budapestre akkreditált külképviseletek rádióhíradását lehallgatták-e ebben az időben.

1932-ben megalakul a VI/2 osztályból a VKF/2 osztály, amely a vezetékes és rádiólehallgató tevékenységért felelt. Technikai eszközeit a Magyar Királyi Honvédelmi Minisztérium 1930-ban kiadott „Hirszerzö Szolgálat ellátására vonatkozó szervezési és müködési szabályzata” alapján a távbeszélő-lehallgató, rádiólehallgató és a rádióiránymérő készülékek képezték.

1935-ben SOMKÚTHY József altábornagy, vezérkari főnök POKORNY Hermannt megbízta a vezérkar rejtjelfejtő osztályának vezetésével. Ebben a minőségében, tapasztalatcsere céljából, erős 
német-magyar kapcsolatok épültek ki és ekkor kezdte tanulmányozni az ENIGMA rejtjelezö berendezést, mint egy később számba jöhető, rendszeresítésre váró eszközt. ${ }^{13}$

A II. világháború első éveiben a 101. híradóezred rádiófelderítő alegységei a keleti fronton tevékenykedtek és információt szereztek a szovjet erők észak kaukázusi arcvonalának mélységében állomásozó 4. szovjet repülőhadsereg-parancsnokság forgalmazásairól.

„Az eddigi 101/II. híradózászlóalj kilép a 101. híradóezred kötelékéből, és mint m. kir. honvéd rádiófelderítő zászlóalj önálló csapattestté válik....."14

1942. X. 1-ig a magyar katonai rádiófelderítés, a híradó szolgálat csapatainak részeként tevékenykedett. Az új zászlóalj Nagyvárad és Budapest helyőrségekben diszlokált.

1942. X. 1-i hatállyal, a 101. zászlóaljból kikülönített erőkből létrehozták a 102. rádióhírszerző zászlóaljat, három századdal, Budapest békehelyőrségben.

A II. világháború alatt a $\mathrm{VKF} / 2$ osztályának „X” alcsoportjának vezetője jó kapcsolatokat ápolt a Reichsicherheisthauptamt (RSHA) [német Birodalmi Biztonsági Főhivatal] VI. osztályának szakembereivel. A rádiólehallgató részleg naponta 8-10 rádióállomást hallgatott le, fóként a Budapestre akkreditált külföldi követségek adásait. A lehallgató- és rádióiránymérő állomások a fővárosban és a föbb településeken müködtek. 1944-ben az RSHA délkelet-európai részlegének vezetöje, Wilhelm HÖTTL SS hauptsturmführer, ${ }^{15}$ látogatást tett a magyar rádió lehallgatóknál, ahol a látottak nagy hatással voltak rá. Úgy találta, hogy a magyarok szegényes személyi és technikai erőforrásaik ellenére nagyon sikeresen dolgoznak.

A híres Codebreakers [Kódfejtők] című könyv szerzője, David KAHN erről úgy nyilatkozott, hogy Wilhelm HÖTTL SS hauptsturmführer szerint magyar rejtjelfejtők a korántsem ideális körülményeik ellenére, viszonylag több információt szereztek, mint a birodalmi külügy- a légügyi minisztérium, a hadsereg és a rendőrség lehallgató szolgálata együttvéve. Wilhelm HÖTTL SS hauptsturmführer fönökét Walter Friedrich SCHELLENBERGet SS-Brigadeführer meggyözték a hallottak és 100000 CHF-t biztosított további felszerelések vásárlására. Hat hónapon belül az egység túlszárnyalta a legvérmesebb reményeket, hiszen a moszkvai nagykövetségek, néhány amerikai, angol és a budapesti török nagykövetség (attaséhivatal) szinte valamennyi rádiótáviratának megfejtésével értékes információkat szereztek. Az utóbbiakból derült ki, hogy Joszipf VISZAIRONOVICS SZAKASVILI [Sztálin] mennyire nem bízott nyugati szövetségeseiben és attól félt, hogy azok különbékét kötnek Németországgal. Alfred Jozef Ferdinand JODL vezérezredes, a Wehrmacht vezérkari fönöke szerint, ebben az időben ezek a hírforrások voltak számára a legmegbízhatóbbak Oroszországgal kapcsolatban. (V.sz. melléklet)

101. rádiófelderítő zászlóalj 1944. évi történetéről mérsékelt forrásanyag maradt fenn, a zászlóalj ekkor Erdélyben állomásozott. ${ }^{16}$

1945 elején a magyar rádiófelderítő erők Purgstall térségében hajtottak végre szaktevékenységet. Az utolsó híradások alapján a zászlóalj erői Schardinget elérve felmorzsolódtak, személyi állományuk egy része amerikai fogságba esett.

1945. január közepén az Ideiglenes Nemzeti Kormány Debrecenben felállította a Honvédelmi Minisztériumot, melyen 1945. III. 3-án megalakították a Katona Politikai Osztályt több alosztállyal: Nyilvántartó alosztály (NYÍL), benne a rádiócsoport, Hírszerző alosztály, X (rejtjelző) alosztály.

Ez volt a háború utáni rádiófelderítés kezdete.

1947. II. 14-én a Katonapolitikai Osztályból megalakul a Katona Politikai Csoportfőnökség, ami a Budapest Nádor utca 9. szám alól átköltözött a Budapest Bartók Béla úti Hadik-laktanyába. Jelenleg ezt az objektumot a Katonai Nemzetbiztonsági Szolgálat használja. A csoportfönökség keretében felállították a Rádiófelderítő Osztályt, majd 50 fövel létrehozták a Rádiófelderítő Csoportfőnökséget (1953-tól Rádiófelderítő Szolgálat), ami 1995-ig tervezte, szervezte, vezette a tevékenységet.

A Rádiófelderítő Szolgálat vezetői a mindenkori felderítő csoportfőnök rádiófelderítő helyettesei voltak. $^{17}$

A háborút követő újjáépítés, a hadsereg újjászervezését is jelentette. A hazatérő tisztekböl, altisztekből álló mobil csoportokkal különböző vételkísérleteket hajtottak végre az ország területén. A Rádiófelderítő Osztály segítségével 1947. VIII. 1-én megalakult az 1. honvéd önálló rádiófelderítő század.

A mai napig 1947. VIII. 1-ét tarjuk a magyar katonai rádiófelderítés születésnapjának, véleményem szerint igaztalanul. Hiszen levéltári adatok szerint az első, önálló rádiófelderítő alakulat 1942. X. 1-ei hatállyal jött létre, igaz Nagyváradon, tehát a jelenlegi Magyarország területén kívül. 1943. X. 1-én, azonban már Budapest helyörséggel müködött egy másik rádió-felderítő alakulat is. Tehát nem 1947. VIII. 1. a rádiófelderítés születésnapja. Néhány évvel ezelött beszélgettem erről a 
témáról a tavaly elhunyt VASS Jenő nyá. ezredessel. Visszaemlékezései alapján az önkényes dátumkijelölés 1975-ben történt meg, amikor megszületett az igény a fegyvernemek, szakcsapatok történetének tudományos igényü feldolgozására. A szocialista Magyar Néphadsereg egyszerüen nem fogadhatott el egy II. világháborús, tehát a HORTHY-korszakra visszanyúló eredetet, így döntöttek 1947 ügyéröl. Talán egyszer eljön az idő ennek tényszerü és történetileg megalapozott felülvizsgálatára és az új dátum kijelölésére. ${ }^{18}$

\section{Magyar rádiófelderítés 1947-1990}

Egy évvel a megalakulása után a 1. honvéd önálló rádiófelderítő század már „éles” feladatokat hajtott végre kitelepülten Írottkőn (Kőszeg) és a Badacsony lejtőjén.

1948-ban a századot 1. önálló rádió-felderítő (RÁF) zászlóaljjá szervezték át. Ekkoriban „örökölt” USA, német és csekély számú magyar szaktechnikai eszköz állt rendelkezésre. (VI.sz. melléklet)

1949. III. 16-án az 1. RÁF zászlóaljból, — átszervezés és feltöltés után — felállították a 101. kiképző és felderítő-lehallgató-iránymérő RÁF zászlóaljat, melyet 1949-1953 között a 102. és 103. zászlóalj felállítása követett. Rendszerint a jogelőd szervezetből kikülönített alegység bázisán és részben annak technikai eszközeivel történtek valósították meg az új alakulatok létrehozását. A 103. zászlóalj kezdetben a Rádió-felderítő Szolgálat alárendeltségében müködött, majd később átkerült az 5. Hadsereg (Székesfehérvár) alárendeltségébe és áttelepült Szombathely helyőrségbe.

A hidegháborús kihívásoknak megfelelően egymást érték az átszervezések, melyek a RÁF alegységeket sem hagytákérintetlenül.

1953-ban a 101., 102. és 103. RÁF zászlóalj összevonásával létrejön az első hadászatihadműveleti RÁF egység, a 102. önálló rádió-felderítő ezred néven, Budapest helyörségben a Budakeszi úti laktanyában. 1953-1954-ben JÁMBOR Gyula alezredes vezetésével megkezdődött a szaktisztek képzése a Híradó Tiszti Iskolán. Jelentősen javult a szaktechnikai eszközpark és megkezdődött a magyar felderítővevők széleskörü alkalmazása. Számos eszköz fejlesztése, mint például a R-1250M, amely SzŐNYI István ezredes nevéhez füződik. (VII.sz. melléklet)

Az ezred - amely az 1956-os magyar forradalom és szabadságharc eseményeiben nem vett részt — ebben a formában 1957-ig müködött.

1957. II. 5-én a Budakeszi úti laktanyakomplexumban létrehozták a 3. önálló (hadászati) rádiófelderítő ezredet (MN2983), amely eröit és eszközeit tekintve megegyezett, szervezeti struktúrájával azonban lényegesen eltért az előd szervezettől, vagyis a 102. önálló (hadászatihadmüveleti) rádiófelderítő ezredtől. ${ }^{19}$

Az ezred 1983-ig hajtott végre szakmai teendőket, szoros együttmüködésben a Varsói Szerződés tagállamainak fegyveres erőivel. Számos sikeresen végrehajtott feladat füződik az ezred személyi állományához. Rendszeresen figyelemmel kisérték az Német Szövetségi Köztársaságban állomásozó Amerikai Egyesült Államok haderejének, valamint az olasz és az osztrák haderő tevékenységét, gyakorlatait.

1962-ben az ezred erői észlelték először, hogy az Atlanti-óceánon megnött a járőrözö, atomfegyvereket hordozó B-52-esek létszáma, ami az Amerikai Egyesült Államok légierejének magasabb harckészültségbe történő helyezését, a készenlét fokozását jelentette a kubai rakétaválság idején.

Az ezrednél számos jól képzett tiszt és tiszthelyettes dolgozott. E mellett az alakulat elé kitüzött célok elérése érdekében a Vakok Intézetével kötött megállapodás kötöttek, amely alapján számos kitünő és kifinomult képességü vak távírász segítette évekig a munkájukatat.

1962-ben létrejött a hadmüveleti szintű rádiófelderítés. A hadászati rádiófelderítő ezred állományából vált ki a 2. RÁF zászlóalj, amely az MN2983/C fedőszámot viselve később a Budapesten a Hidász utcába költözött és felvette a MN5341 számot. ${ }^{20}$

A Magyar Néphadseregben az 1967. esztendő jelentette az új felderítési nem kialakulásának kezdetét, amikor a Vezérkar Felderítő (2.) Csoportfönöksége felállította a 26. önálló rádiótechnikai felderítő zászlóaljat (Keszthely). ${ }^{\mathbf{2 1}}$

Ekkor jelent meg a felderítési nemek között az ELINT, amely a COMINT-tal egyetemben képetei a SIGINT-et a nemzetközi terminológiában. ${ }^{22}$

1974-ben a 26. önálló rádiótechnikai felderítő zászlóalj a vezérkar alárendeltségéből a 3. önálló rádiófelderítő ezred szervezeti alárendeltségébe került, megszületett a „rádióelektronikai felderítő” terminológia. (VIII.sz. melléklet)

A hadmüveleti-harcászati rádiófelderítés fénykorában az 5 . hadsereg közvetlen alárendeltségében egy RÁF zászlóalj teljesített szolgálatot, később pedig valamennyi hadosztály állományában még egy- 
egy RÁF századdal rendelkező felderítő zászlóaljat hoztak létre. Az első RÁF századot 1964-ben állították fel, melyet több is követett:

- 8. gépesített lövész hadosztály (MN4981) alárendeltségében a 42. felderítő zászlóalj (MN9027) kötelékében Újdörögd, majd Szombathely elhelyezéssel;

- 9. gépesített lövész hadosztály (MN7203) alárendeltségében az 54. felderítő zászlóalj (MN7842) kötelékében Kaposvár, majd Lenti elhelyezéssel;

- 11. harckocsizó hadosztály (MN2284) alárendeltségében a 74. felderítő zászlóalj (MN9550) kötelékében Tata, majd Györ elhelyezéssel;

- 7. gépesített lövész hadosztály (MN4127) alárendeltségében a 113. felderítő zászlóalj (MN1914) Kiskunfélegyháza elhelyezéssel. ${ }^{23}$

Ebben az időszakban a magyar katonai rádiófelderítés — a vezérkar közvetlen alárendeltségében $\mathrm{n}$ müködő - hadászati teendőket ellátó Budapesten disszlokáló 3. önálló RÁF ezredbő és az 5. Hadsereg alárendeltségébe tartozó Szombathelyen állomásozó 2. önálló RÁF zászlóaljból, továbbá a hadosztályok felderítő zászlóaljainak RÁF századaiból állt. A hadászati, hadműveleti és harcászati RÁF tagozat jól kiegészítette egymást, kiképzésben, szakmai tevékenységben egyaránt kitünően együttmüködtek. (IX.sz. melléklet)

1983-ban a 3. önálló RÁF ezredet, 3. önálló RÁF dandárrá szervezték, az alakulat ekkor érte el szervezetét, létszámát és feladatrendszerét tekintve egyaránt történetének csúcspontját. A dandár 1990től Magyar Honvédség Távközlési Kutató és Ellenőrző Intézet (TÁVKEI) néven folytatta tevékenységét.

A nemzetbiztonsági szolgálatokról szóló törvény ${ }^{24}$ hatálybalépését követően a TÁVKEI kivált a Magyar Honvédség kötelékéből és újjáalakult Magyar Köztársaság Katonai Felderítő Hivatal (MK KFH) néven, melynek integráns részét képezte a Rádióelektronikai Felderítő Igazgatóság (RFI). 2012. I. 1-én a Magyar Köztársaság Katonai Felderítő Hivatala átalakult Katonai Nemzetbiztonsági Szolgálattá (KNBSZ). A KNBSZ részét képezi a Rádióelektronikai Felderítő Igazgatóság utódszervezete a Technikai Felderítő Igazgatóság, amelynek a szakmai feladatai harmonizálnak az elődszervezet tevékenységével. ${ }^{25}$

A hadászati rádiófelderítést 1947-2013 között 16 vezető irányítása alatt állt. ${ }^{26}$

A Magyar Néphadsereg, majd 1991-től a Magyar Honvédség hadműveleti szintű rádióelektronikai felderítése 1992. VIII. 1-vel szünt meg, amikor az új honvédelmi koncepció következtében megalakultak az MH. elektronikai harc szervezetek. A Szombathelyen diszlokáló 2. önálló rádiófelderítő zászlóalj és a Békéscsabán állomásozó 63. önálló rádió és rádiótechnikai zavarózászlóalj összevonásával létrehozták Kiskunfélegyházán az 5. elektronikai harc ezredet. Ezzel párhuzamosan a jugoszláv háború tapasztalatai alapján - felállították az elektronikai harc századokat Győrött, Egerben és Pécsett. Ezek az alegységeket 1996-1997-ben számolták fel, a technikai eszközeiket pedig Kiskunfélegyházára csoportosították. (X.sz. melléklet)

A Magyar Honvédség 5. „Kiskun”elektronikai harc ezredet 2001. VI. 30-án felszámolták. A magyar katonai rádiófelderítés szakmai mélypontját az Magyar Honvédség 24. felderítő zászlóalj Egerből Debrecenbe történő áttelepítése idején érte el, amikor az Magyar Honvédség szervezetében mindössze egy elektronikai hadviselésre alkalmas szakasz maradt. ${ }^{27}$

Ma az egyetlen szárazföldi, szervezetszerü elektronikai hadviselés (rádiófelderítő) képesség a kötelékben lévő Magyar Honvédség 5/24 „Bornemissza Gergely” felderítő zászlóaljnál rendszeresített elektromos hadviselést végző század formájában létezik.

Jelenleg a magyar katonai rádiófelderítést a Katonai Nemzetbiztonsági Szolgálat alárendeltségében működő, hadászati feladatokat ellátó, budapesti elhelyezésű Technikai Felderítő Igazgatóság kötelékében egy Debrecenben állomásozó, harcászati elektronikai hadviselést megvalósító század képezi.

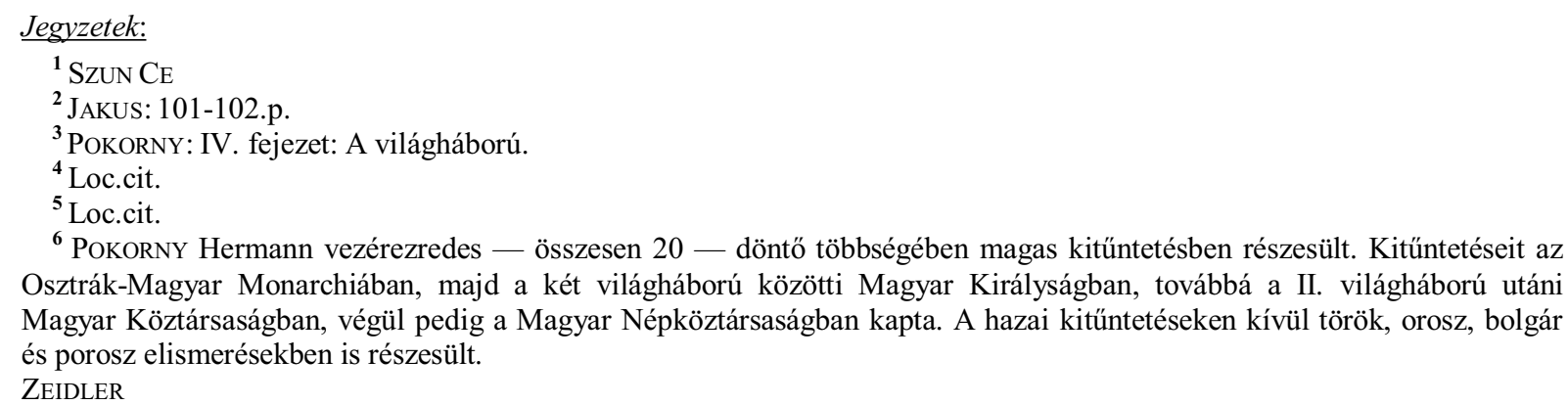


${ }^{7}$ Az Evidenzbüro az Osztrák-Magyar Monarchia egyetlen felderítő szervezete volt, amely a haderő kötelékében, a vezérkar alárendeltségében müködött.

PARÁDI ; PILCH: I.köt. 319-362.p. , II.köt. 11-21.p.

${ }^{8}$ Ekkoriban a Honvédelmi Minisztérium VI. Csoportfőnöksége volt a rejtett Honvéd Vezérkar, ami ebben a formában 1932-ig müködött. A VI/2. osztály volt felelős a hírszerzésért és kémelhárításért. 1932-ben GöMBös Gyula parancsára a VI. Csoportfőnökség 2. osztályából szervezték meg a VKF 2 osztályt. Ez a hadrendi elnevezés végigkísérte a magyar katonai hírszerzés történetét, egészen a Honvéd Vezérkar Katonai Felderítő Hivatal 1990-es felállításáig.

${ }^{9}$ POKORNY Hermann visszaemlékezései alapján megállapítható, hogy el lehetett kerülni a hadsereg teljes mozgósítását a „budaörsi ütközetként” elhíresült esemény kapcsán, amikor jelentette, hogy nem kell tartani a kis- antant támadásától, és IV. Károlyt a vártnál kisebb erők támogatják.

POKORNY : op,cit. : VI. fejezet: A vezérkarban, csapatszolgálatban.

10 „A Magyar Királyi Vámörség 1921. VIII. 25 - 1932. X. 1. müködött a pénzügyi tárca látszólagos felügyeletével. A valóságban azonban — az ország védelmi képességének elősegítése céljából, a határőrizeti legális feladatkör rejtésében — a testület fedésében katonai erőket csoportosítottak a határra. A Szövetségközi Katonai Ellenőrző Bizottság magyarországi tevékenységének beszüntetése után, 1927-től a Magyar Királyi Honvédség gyalogezredeinek 1/3-a a Magyar Királyi Vámőrség rejtésében a határok mentén diszlokált. A Magyar Királyi Vámőrség élén a vámőrség vezérfelügyelöje állt, tevékenységét a Vámőr Főparancsnokság segítette. A testület 7 kerületből állt: Budapest, Győr, Szombathely, Kaposvár, Szeged, Debrecen és Miskolc székhellyel. A vámőr kerületek székhelyei és az őrizetükre bízott határszakaszok megegyeztek a Magyar Királyi Honvédség vegyesdandárainak székhelyeivel és határszakaszaival. A vámör kerületek alárendeltségeibe a vámőr szakaszok tartoztak, összesen 54 szakasz. A vámör szakaszok pedig a vámőr örsöket irányították, amelyek a testület legkisebb szervezeti egységeit alkották. Összességében 153 vámőr örs müködött. A Magyar Királyi vámőrség személyi állományának a létszáma —a szervezet rejtésében müködő honvédezredek nélkül — 4500 fő körüli volt. A bujtatott honvéd ezredek honvédségi egyenruhát és rangot viseltek, a honvédségnél rendszeresített haditechnikával rendelkeztek. A Magyar Királyi Vámőrség önálló egyenruhával és rendfokozati rendszerrel, valamint csupán kézi lőfegyverekkel rendelkezett. A testület legénységi állományát úgynevezett kényszertoborzás (sorozás) útján biztosították. A vámőri rangoknak a katonai rangrendszerben volt párhuzamos megfelelője. A Magyar Királyi Vámőrséghez helyezett katonák a katonai rangjuknak megfelelő vámőri rangot kaptak és visszahelyezésük alkalmával azt a katonai rangot kapták, amilyen rangot a vámőrségnél elértek, illetve annak megfelelö katonai rangot. A vámörség személyi állomány ugyan hivatalosan a pénzügyi tárcához tartozott, a valóságban azonban — bujtatott módon, a Magyar Királyi Csendőrség személyi állományához hasonlóan a honvédelmi tárca diszponált a személyügyi témák felett."

ZEIDLER : op.cit. : 62.p.

${ }^{11}$ A Nemzeti Emlékhely és Kegyeleti Bizottság Pest megyében a Nemzeti Sírkert részévé nyilvánította sírját. (Gödöllő, Dózsa György úti temető Parcella: Bal II. Sor:6 Sír:13-17 Név: POKORNY Hermann vezérezredes.)

12 1927. III. 31. Az Antant hatalmak megszüntették a Szövetségközi Ellenőrző Bizottság magyarországi működését.

${ }^{13}$ DÉKÁNY - SZÖNYI: 8-10.p.

${ }^{14}$ Az átszervezésre a 42/1942.HM.intézkedésben foglaltak szerint kerül sor. BAJNAI: 48.p.

${ }^{15} \mathrm{SS}=$ Schutzstaffel [Védőosztag] a Német Nemzetiszocialista Munkáspárt katonai és védelmi szervezete volt. Az SS 1925-től 1945-ig működött. Az SS nem csak rendfenntartó testületként müködött, hanem a II. világháború hadmủveleteiben is részt vett. Az SS önálló rendfokozati rendszerrel rendelkezett.

SS rendfokozatok:

- Sturmmann $\quad=\quad$ közlegény

- Rottenführer $\quad=\quad$ örvezető

- Unterscharführer $\quad=\quad$ tizedes

- Scharführer = szakaszvezető

- Oberscharführer = örmester

- Hauptscharführer = törzsőrmester

- Sturmscharführer = fötörzsőrmester

- Untersturmführer = hadnagy

- Obersturmführer = fóhadnagy

- Hauptsturmführer = százados

- Sturmbannführer = örnagy

- Obersturmmannfüherer $=\quad$ alezredes

- Standartenführer $=$ ezredes

- Oberführer = $\quad=\quad$ ezredes és dandártábornok

- Brigadeführer $\quad=\quad$ dandártábornok

- Gruppenführer $\quad=\quad$ vezérezredes

- Oberstgruppenführer $=$ tábornagy

${ }^{16}$ A m. kir. honvédelmi miniszter 1943. XII. 20-án kiadott - minősítési jogosultság megállapítására vonatkozó utasításából kiderül, hogy a hadmüveleti rendeltetésủ 101. ráf. zlj. a IX. hadtest közvetlen alárendeltségébe tartozott. A hadtestet az erdélyi terület visszacsatolásakor állították fel és parancsnoksága akkor Kolozsvárott állomásozott. 1944. IV. 15én még ott volt. A 101. ráf. zászlóalj akkor Nagyváradon állomásozott.

BAJNAI: op.cit. 49.p.

${ }^{17}$ A Rádiófelderítő Szolgálat vezetői

- LeHOCZKy András alez.

- KAPCSOS Zoltán ezds.

- PÁszKa Géza ezds.

- Dr Schneider Pál ezds.

- FLiszÁr László ezds.

- LAKATos József ezds. 
- FeKETE Flórián ezds.

- GYENES István ezds.

VÁRHEGYI: A magyar rádiófelderítés müködése a hidegháború éveiben. 56-57.p.

${ }^{18}$ Az MK Katonai Felderítő Hivatalban (jelenleg Katonai Nemzetbiztonsági Szolgálat) megtalálható egykori, hiteles és eredeti dokumentum igazolja, hogy 1974-ben LAKATOS József ezredes, a 3. önálló rádiófelderítő ezred parancsnoka kérvényezte a jogelőd szervezet megállapítását, annak megalakulási időpontjával együtt. PÁszKA Géza ezredes, az elöljáró MNVK 2. Csoportfönökség, csoportfönök első helyettese válaszolt a felterjesztésre. E szerint a 15 000/1947.HM.r. hatályát 1947. VI. 23-át kell a jogelőd szervezet megalakulása időpontjának tekinteni.

${ }^{19}$ VÁRHEGYi: A magyar katonai rádióelektronikai felderítés története 1945-1990. : 210.p.

${ }^{20}$ Később Szombathelyre diszlokált és 1992-ben szünt meg, a Magyar Honvédség Elektronikai Hadviselési koncepciójának megszületésekor.

${ }^{21}$ CZUTH: 83.p.

${ }^{22}$ ELINT $=$ COMINT $=$

Electronic Intelligence (rádiótechnikai felderítés)

SIGINT $=$

Communication Intelligence (rádiófelderítés)

${ }^{23}$ HEKLI: 124.p.

${ }^{24}$ 1995/CXXV.tv

${ }^{25}$ BODA: 316.p.

${ }^{26}$ A magyar hadászati rádiófelderítés vezetöi 1947-1913 között idörendi sorrendben: 1. DETREKöI Emil örnagy,

2. GyURICZA Imre alezredes, 3. KAPCSOs Zoltán örnagy, 4. Tóth Gyula örnagy, 5. GyURICZA Imre alezredes, 6. KAPÁs Pál alezredes, 7. KAPCsos Zoltán alezredes, 8. dr. Demeter György alezredes, 9. LAKATOS József ezredess, 10. LuKÁCs László ezredes, 11. IHÁsz Dezső ezredes, 12. JAKAB József ezredes, 13. GyENEs István müszaki ezredes, 14. PÁszKA Tibor müszaki. ezredes, 15. SERES Antal müszaki. ezredes, 16. BALOGH Péter müszaki ezredes.

${ }^{27}$ „Az Elektronikai hadviselés egy olyan katonai tevékenység, amely magában foglalja az elektromágneses tér és az irányított energia felhasználását abból a célból, hogy ellenőrizze az elektromágneses spektrumot és támadást hajthasson végre az ellenség ellen. Felosztása: elektronikai támogatás, elektronikai támadás és elektronikai védelem.”Az elektronikai támogatás, tevékenységében, módszereiben, alapvető céljaiban harcászati szinten, azonos a rádiófelderítéssel.

Az FM 3-36 Electronic Warfare Overview (25 February 2009) 1-5 és a JP 3-13.1 dokumentum NATO dokumentum alapján:

\section{A jegyzetekben alkalmazott röviditések:}

\section{MONOGRÁFIÁK ÉS KISMONOGRÁFIÁK}

DÉKÁNY - SZÖNYI - DÉKÁNY István - SZÖNYI István: A magyar katonai rádiófelderítés története. Budapest, 2009, Zrínyi Kiadó. 110 p.HU-ISBN 9789633274651

PILCH

PILCH Jenő: A hirszerzés és kémkedés története. Budapest, 1936, Franklin. I.köt. 367 p. II.köt. 402 p. III.köt. 386 p.

POKORNY

POKORNY Hermann: Emlékeim, a láthatatlan hírszerző. Budapest Kalocsa, 2000, Petit Reál - Kaloprint. 168 p. HU-ISBN 9639267031. /Hadtörténeti levéltári kiadványok./ HU-ISSN 1417-9598.

SzUn CE

SzUn CE (Ping Fa): A hadviselés törvényei. Ford.: TÖKEI Ferenc. Budapest, 1938, Balassi. 118 p. HU-ISBN 963506194 3. /Kínai-magyar könyvek, 5./ HU-ISSN 1218-6600.

Országos Széchenyi Könyvtár Elektronikus dokumentum Központ Magyar Elektronikus könyvtár. Világhálón:

http://www.mek.oszk.hu/01300/01345/01345.htm

Letöltés ideje: 2013. X. 15.

\section{TANULMÁNYOK}

BAJNAI

BODA

CzUTH

HEKLI

JAKUS

PARÁDI
- BAJNAI Gusztáv: A magyar rádiófelderítés kialakulása és müködése a kezdetektől a második világháború végéig. Felderitő Szemle, VI.évf. (2007) Emlékszám, 37-52.p. HU-ISSN 1588-242X.

- Boda József: Nemzetbiztonsági szolgálatok 2010 után. 307-344.p. In BoDA József - PARÁdi József - SimON F. Nándor (szerk.): A XIX-XX. századi magyar állam nemzetbiztonsági szervezetei. Budapest, 2013, Nemzetbiztonsági Szakszolgálat. 358 p. HU-ISBN 9789630858564.

- Czuth László: A rádiótechnikai felderítés(ELINT). Felderítő Szemle, VI.évf., Emlékszám, 83-120.p. HU-ISSN 1588-242X.

- HeKLi László: A harcászati és a hadműveleti rádióelektronikai felderítés története. Felderitö Szemle, VI.évf. (2007) Emlékszám, 121-160.p. HU-ISSN 1588-242X.

- JAKUS János: A magyar rádió- és rádióelektronikai felderítés szervezeti változásai 1990-ig. Rendvédelem-történeti Füzetek (Acta Historiae Preasidii Ordinis), XXIII.évf. (2013) 27-28-29-30.sz. 101-110.p. HU-ISSN 1216-6774.

PARÁDI József: Az Evidenzbüro. 33-54.p. In BoDA József — PARÁDI József SIMON F. Nándor (szerk.): A XIX-XX. századi magyar állam nemzetbiztonsági szervezetei. Budapest, 2013, Nemzetbiztonsági Szakszolgálat. 358 p. HU-ISBN 9789630858564. 
VÁRHEGYI: A magyar rádiófelderítés működése a hidegháború éveiben.

VÁRHEGYI: A magyar katonai rádióelektronikai felderítés története 1945-1990.

ZEIDLER

\section{JOGSZABÁLYOK}

1995/CXXV.tv.

\section{Mellékletek jegyzéke:}

I.sz. melléklet

Rádiólehallgatás az orosz fronton.

II.sz. melléklet

POKORNY Hermann rádiólehallgató szolgálatának munkatársai.

III.sz. melléklet

POKORNY Hermann örnagyként 1917-ben.

IV.sz.melléklet

POKORNY Hermann életútjának föbb állomásai.

V.sz. melléklet

Wilhelm HӧттL Hauptsturmführer (1935-ben).

VI.sz. melléklet

A Halicrafters SX 42 vevökészüléket a magyar rádió-felderités Rv-200 modellként használta 1947-1950 között.

VII.sz. melléklet

$R-1250$ rádióvevö.

VIII.sz. melléklet

Egy szovjet SzDR-2M típusú rádiótechnikai felderitö berendezés.

IX.sz. melléklet

Magyar gyártmányú REV-251 rövidhullámú felderitővevök.

X.sz. melléklet

VU-141 URH RÁF állomások telepitve.
VÁRHEGYI István: A magyar rádiófelderítés müködése a hidegháború $1588-242 \mathrm{X}$.

- VÁRHEGYI István: A magyar katonai rádióelektronikai felderítés története 1945-1990. Felderitö Szemle, VI.évf. (2007) Emlékszám, 181-198.p. HUISSN 1588-242X.

- ZEIDler Sándor: Pokorny Hermann vezérezredes kitüntetései és ami mögötte van. 55-100.p. In BODA József — PARÁdI József — SIMON F. Nándor (szerk.): A XIX-XX. századi magyar állam nemzetbiztonsági szervezetei. Budapest, 2013, Nemzetbiztonsági Szakszolgálat. 358 p. HU-ISBN 978963 0858564 .

- 1995/CXXV.tv. a nemzetbiztonsági szolgálatokról.

\section{Rádiólehallgatás az orosz fronton.}

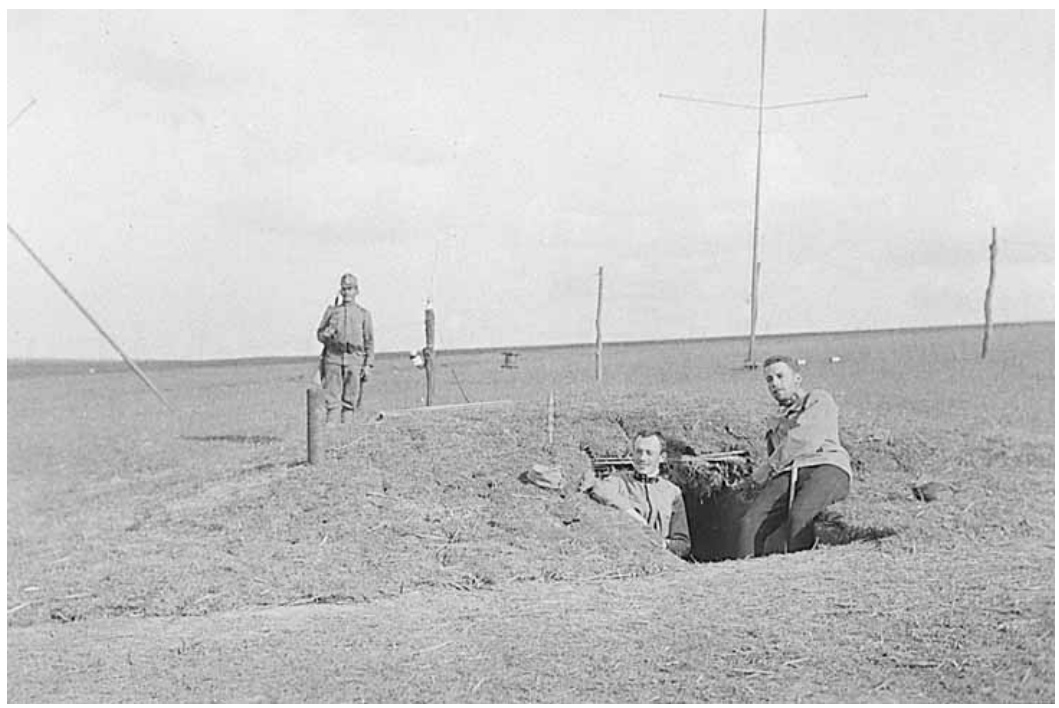

Forrás ! POKORNY Hermann: Emlékeim, a láthatatlan hírszerzö. Budapest - Kalocsa, 2000, Petit Reál - Kaloprint. 168 p. HU-ISBN 963926703 1. /Hadtörténeti levéltári kiadványok./ HU-ISSN 1417-9598.

Világhálón: http://www.mek.oszk.hu/02000/02095/html/images/f5.jpg

Letöltés ideje: 2013. X. 10. 


\section{Pokorny Hermann rádiólehallgató szolgálatának munkatársai.}

II.sz. melléklet

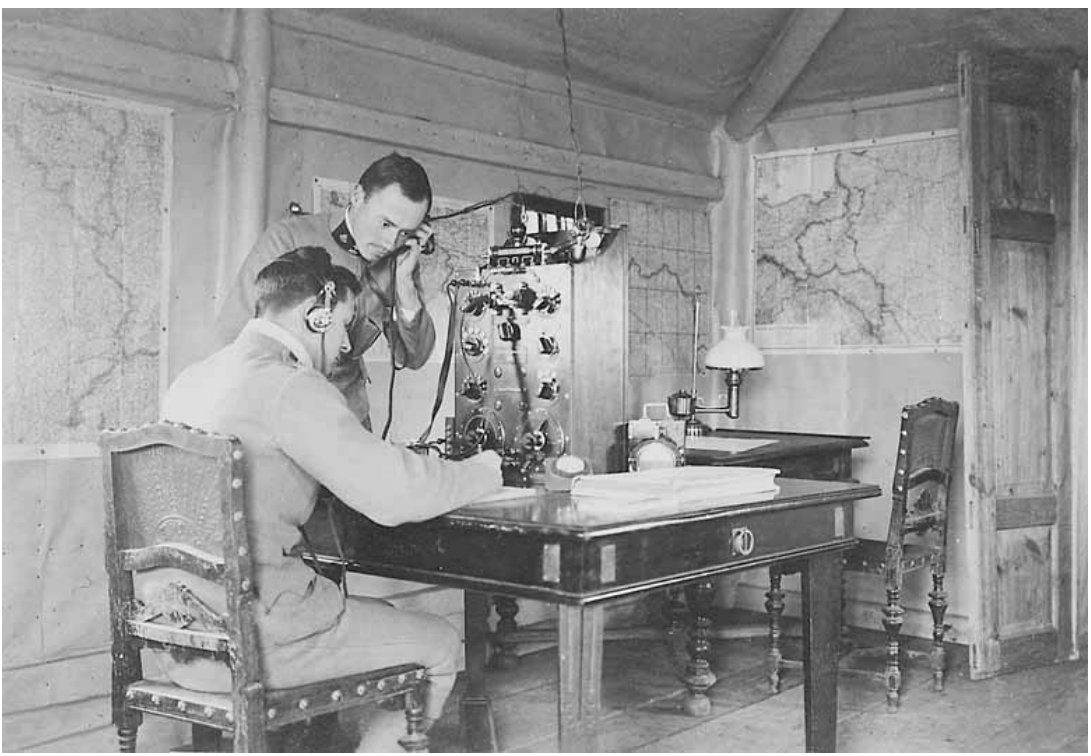

Forrás ! POKORNY Hermann: Emlékeim, a láthatatlan hírszerzö. Budapest - Kalocsa, 2000, Petit Reál - Kaloprint. 168 p. HU-ISBN 963926703 1. /Hadtörténeti levéltári kiadványok./ HU-ISSN 1417-9598.

Világhálón: http://www.mek.oszk.hu/02000/02095/html/images/f4.jpg

Letöltés ideje: 2013. X. 10.

\section{POKORNY Hermann örnagyként 1917-ben.}

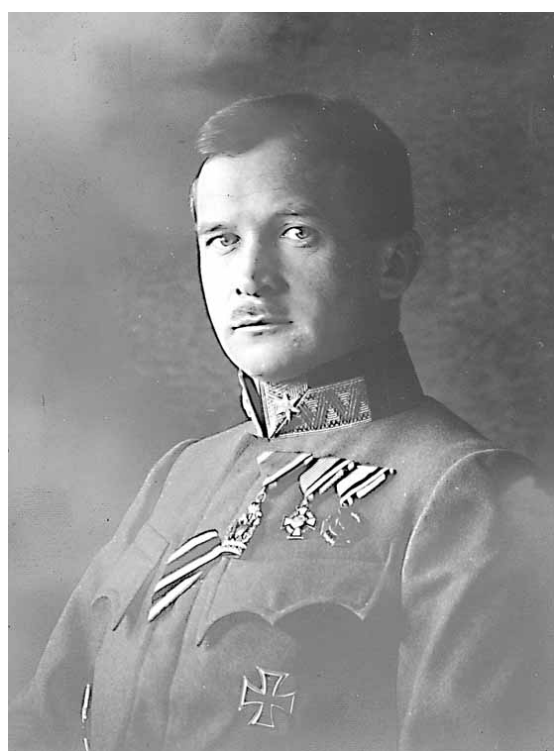

Forrás ! POKORNY Hermann: Emlékeim, a láthatatlan hírszerzö. Budapest - Kalocsa, 2000, Petit Reál - Kaloprint. 168 p. HU-ISBN 963926703 1. /Hadtörténeti levéltári kiadványok./ HU-ISSN 1417-9598.

Világhálón: http://www.mek.oszk.hu/02000/02095/html/images/f52.jpg

Letöltés ideje: 2013. X. 8. 


\section{РокоRNy Hermann életútjának föbb állomásai.}

1897. augusztus 20 .

1900. augusztus 18.

1900-1903.

1903-1904.

1904-1906.

1906. október

1909 ősze

1909. szeptember-október

1910. március

1913. február-november

1914. augusztus

1914. szeptember-1916. március

1916. augusztus

1917. november-1918. március

1918. november

1920. április-július

1920. július-október

1920. november-1925. április

1925. április-november

1925. december

1926. április-1928. október

1930. május-1934. május

1935. május

1945. január-február

1945. február-1949. február

1949. február
Bécs, k. k. Landwehr hadapródiskola

Felavatás után bécsi k. k. Landwehr gyalogezred

Hütteldorf, bécsi k. k. 1. Landwehr gyalogezred III. zlj. 9. sz.

Bécs, fötiszti tanfolyam

Bécs, Hadiiskola

Graz, k. k. 43. Landwehr dandár

Graz, III. hadtestparancsnokság

Bulgária

Bécs, Instruktionsbüro des Generalstabes

Oroszország

Teschen, hadsereg-föparancsnokság

rádiólehallgatás a k. u. k. 2., 3., 4. és a Mackensen hadseregparancsnokságnál

k. k. 26. Landwehr gyalogezred

Breszt-Litovszk, fegyverszüneti delegáció

Bécs, magyar szolgálatban

Debrecen, vasi gyalogezred debreceni zlj.

Krím, Vrangel-hadsereg

VKF Nyilvántartó iroda, "X" csoport

Szeged, vegyesdandár

Budapest, VKF "B" csoport

Budapest, Budapesti Vámőrkerület

Miskolc, VII. vegyesdandár

nyugdíjazás

Heves, Rogyin Jakovlevics Malinovszkij marsall föparancsnoksága

Budapest, Külügyminisztérium

végleges nyugdíjazás

Forrás ! POKORNY Hermann: Emlékeim, a láthatatlan hírszerző. Budapest - Kalocsa, 2000, Petit Reál - Kaloprint. 168 p. HU-ISBN 963926703 1. /Hadtörténeti levéltári kiadványok./ HU-ISSN 1417-9598.

\section{Wilhelm HöTTL Hauptsturmführer (1935-ben)}

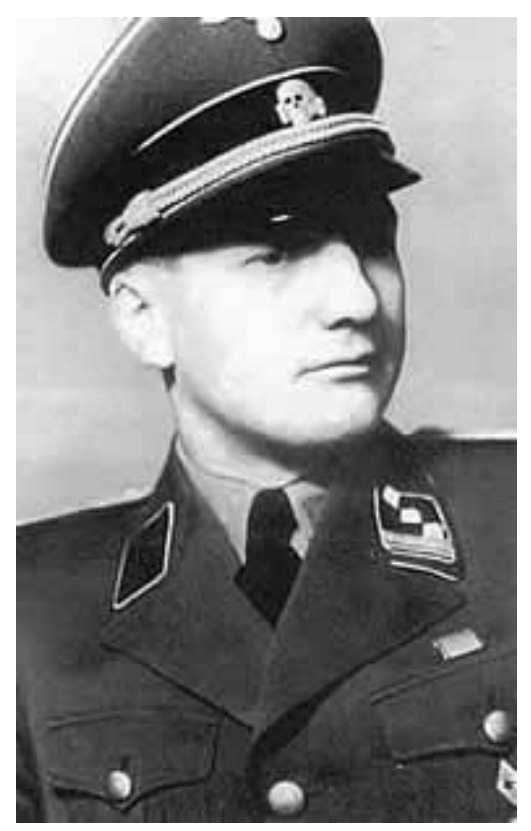

Forrás ! Forrás: http://www.holocaustresearchproject.org/nazioccupation/images/hoettl.JPG Letöltés ideje: 2013. X. 21. 


\section{A Halicrafters $S X 42$ vevökészüléket a magyar rádió-felderités}

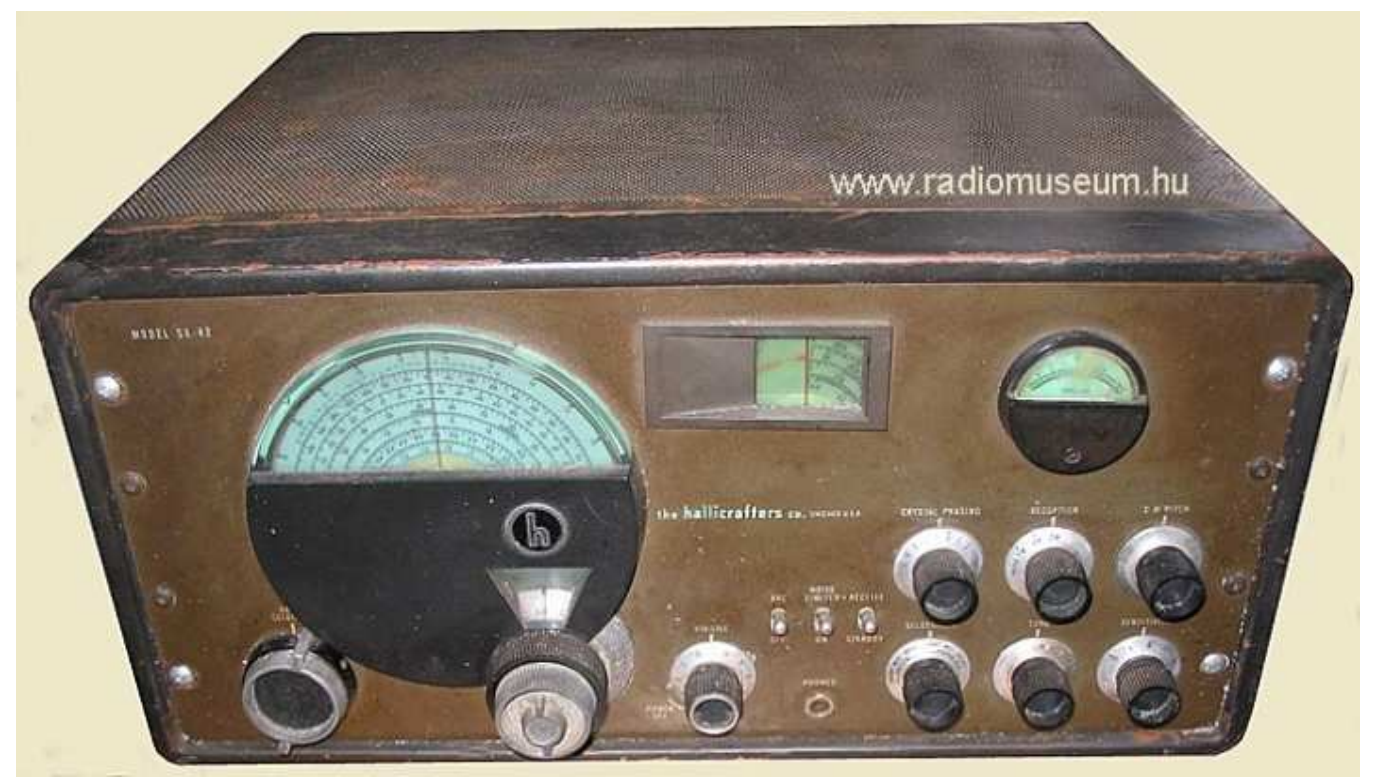

A képen látható Hallicrafters SX-42 típusú vevőkészüléket az 1947-1950-es évek között a honvédségen belül a rádiófelderítés (RÁF) használta. A II. vh. után az osztrák ELTZ, a magyar Zelenka vevőkészülékei mellett az angol Redifon (R-50), a BC-342, BC-348 a BC431 (USA) Ediston és Rhode Schwarz kommunikációs vevőkészülékeit alkalmazták.

Forrás ! http://www.radiomuseum.hu/sx42.html

Letöltés ideje: 2013. X. 22.

VII.sz. melléklet

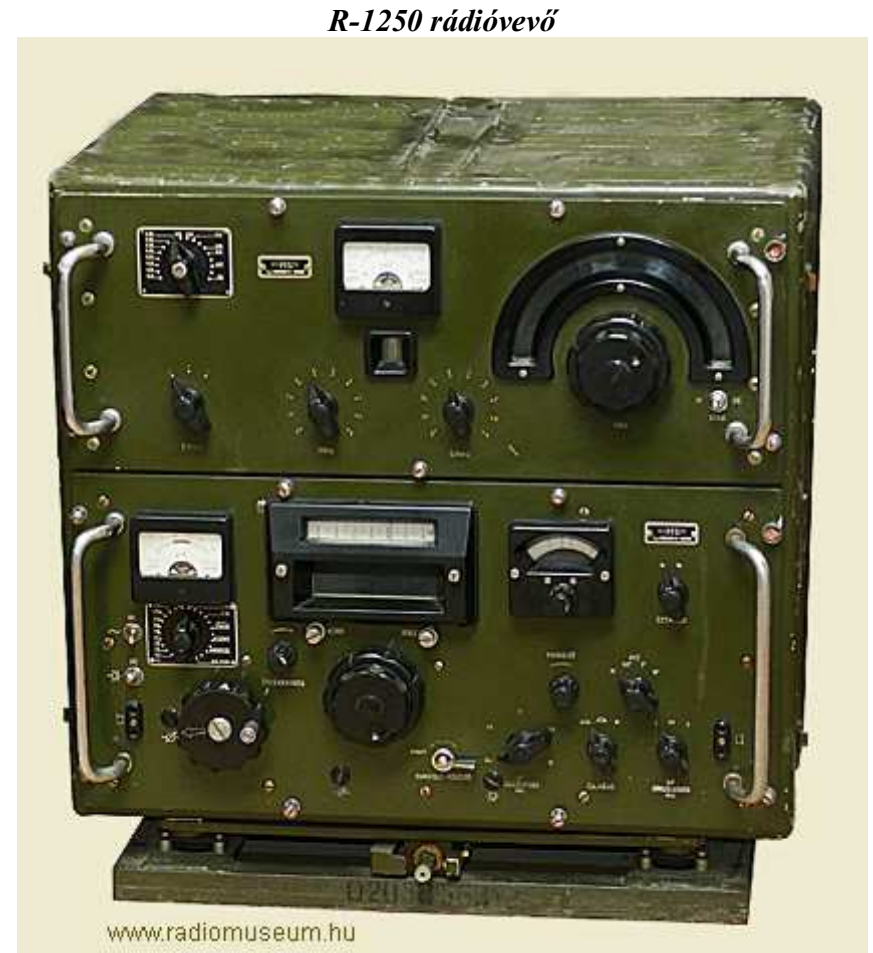

ML 400-as vevőt 1963-ig használták, de egyre fontosabbá vált a frekvenciapontosság és a stabilitás. 1960-1961-ben elkezdték tervezni az R-1250-es szintéteres vevőkészüléket. A készülék nagyon jól sikerült, az egyik legjobb rövidhullámú készülék lett, stabil volt, minden akkor ismert üzemmódban használható volt. A nagy stabilitást és pontosságot a szintéterben alkalmazott kvarckristály termosztátba helyezésével érték el. A készülék hasonlít az orosz R-250-re. Ezek a készülékek a rádióamatőrök körében még ma is népszerüek.

Forrás ! http://www.radiomuseum.hu/ml1250.html

Letöltés ideje: 2013. X. 10. 


\section{Egy szovjet SzDR-2M típusú rádiótechnikai felderítö berendezés}

VIII.sz. melléklet

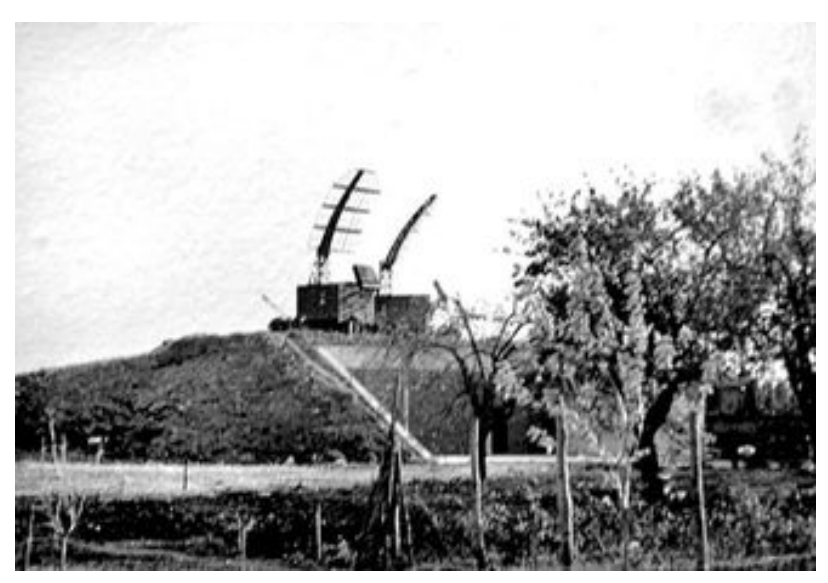

Az SzDR 2M rádiótechnikai felderítő berendezést a magyar rádióelektronikai felderítés széleskörűen használta egészen 2003-ig. A kép forrása: Lencsés Károly: A magyar rádiófelderítők a Földközi-tengert figyelték.

Forrás! http://www.nol.hu/archivum/archiv-403485

Letöltés ideje : 2012.10.12.

Magyar gyártmányú R-251 rövidhullámú felderítővevök.

IX.sz. melléklet

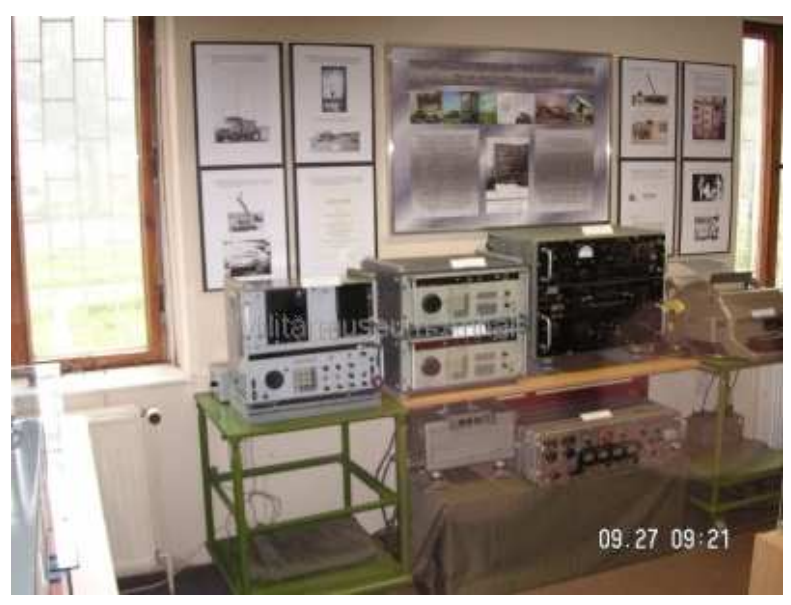

Forrás !

http://www.militaermuseum-anhalt.de/index.php?option=com_rsgallery2\&page=inline\&id=59\&Itemid=54

Letöltés ideje : 2013. X. 24.

\section{VU-141 URH RÁF állomások telepítve}

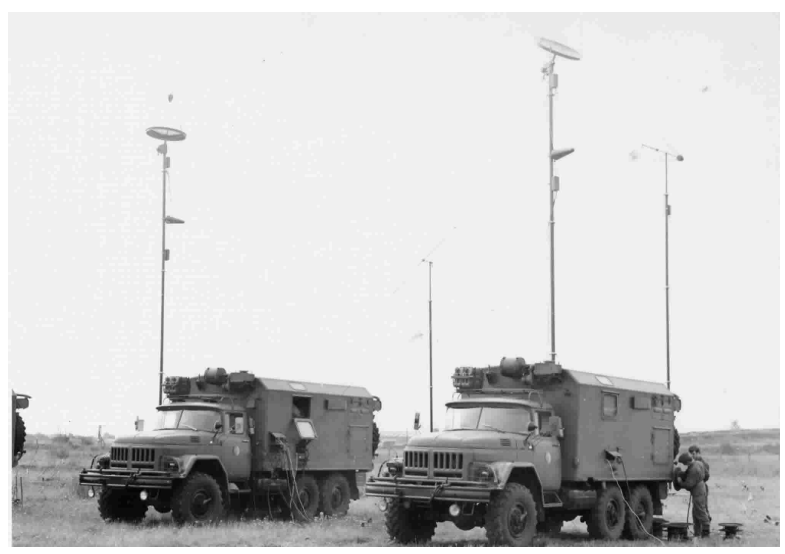

A Magyar Néphadseregben 1976-ban rendszeresítették a VU-141 M/CS URH rádiórelé lehallgató állomásokat. Forrás ! http://www.vogl-dessau.de/UKW.htm 